excursion. The members returned to town by the $6.3 \mathrm{I}$ train from Hendon.

\title{
REFERENCES.
}

Geological Survey Map, Sheet 7 (Drift Edition.)

New Ordnance Survey Map, Sheet 256.

I889. Whit AKer, W.-"Geology of London." Mem. Geol. Survey.

189I. HICKS, H.- "Recently exposed Sections in the Glacial Deposits at Hendon." Quart. Gourn. Geol. Soc., vol. xlvii, p. 575.

1892. Hicks, H.- "Report of Excursion to Hendon and Finchley." Proc. Geol. Assoc., vol. xii, p. 334 .

\section{EXCURSION TO DORKING AND LEITH HILL.}

\author{
Saturday, May 2ND, I896. \\ Director: Thos. Leighton, F.G.S. \\ Excursion Secretary: W. P. D. Stebbing, F.G.S. \\ (Report by THe DIRECTOR.)
}

THE object of this excursion was to study the lithological changes in the so-called Hythe Beds of the Lower Greensand from south to north, between Leith Hill and Dorking, as set forth by the Director in a paper printed by the Geological Society (see References, 1895). The occasion is rendered memorable by the discovery of the Bargate Stone in Punch-Bowl Lane, Dorking, underneath the Pepper and Salt Sands of the same series, which were utilised by the Director in the same paper to connect the Bargate Beds of Wotton with the Nutfield beds of Reigate. The outcrop of Bargate Stone now first recorded lies within the area stated by the Director to be occupied by that series; it is three miles east of any previous record of beds of Bargate Stone, and five miles west of Bell Street, Reigate, where the Bargate Sands are next seen approximately at the same horizon above the Atherfield Clay. The discovery is important in that it proves the value of the Sands, which are more frequently exposed, for the purposes of mapping. This is not by any means the first occasion upon which important facts have been brought to light on the excursions of the Association.

A party of thirty assembled at the Dorking station (L.B. \& S.C.R.), and walked to Punch-Bowl Lane, where, after briefly pointing out the geological features of the district, the Director called attention to the section of Bargate Sands with the usual lydite and other pebbles underlying typical Folkestone Sands. JuLY, I896.] 
The Bargate Sands here correspond exactly to "Bargate Beds" (a) of the section on page 104, op. cit. Further along the lane, to the south, the Bargate Stone was seen as stated above, cropping out in the low bank on the roadside and in the gutter. The outcrop is immediately under the Sands, some dozen paces south, but future visitors are recommended to examine the locality in the early spring, when the bank is free from vegetation and dead leaves. The stone is quite of typical character, a hard calcareous grit, here rather fine in texture, the cementing material slightly crystalline, with fragmentary fossils and needle-shaped sponge spicules. Proceeding south. the sandy nature of the beds below the Bargates was pointed out, overlain by, in several places, drift consisting of chert and Bargate Pebbles. This Drift, the Director pointed out, must have been brought by the Mole from the south, and is derived from beds originally laid down over Holmwood Common to the east of Leith Hill. At the outcrop of the Atherfield Clay at the southern end of the cutting through the Lower Greensand escarpment, the Director pointed out how the horizon of the clay could be mapped without a section by the moisture at the roadside.

From this place the party drove to Chart Lane to the west, where a similar, but better, section of the sandy area of the Lower Greensand was seen. Over the Atherfield Clay are iron sands (Local Group 4), then the clayey sands with phosphatic nodules into which the chert beds of Leith Hill pass northwards, then, although not shown in this lane, the Bargate Beds followed by the Folkestone Sands. The high-level drift of chert and Bargate pebbles was well seen in this lane. The party then drove to Coast Hill, Wotton, and examined, for the sake of comparison, the well-known section of Bargate Stone at the Rookery fault. South-west of the fault the Leith Hill cherts are seen, $60 \mathrm{ft}$. thick. The Director stated that the appearance of chert so far north on this horizon was unusual; east and west these beds were represented by clayey sands. It was also pointed out that this section showed slightly intermediate conditions, some falsebedding appearing, and sand forming the mass of the rock, although there was plenty of chert with it. In its passage south even this sandy chert (the upper division or northern facies of the Leith Hill beds) became more of a sponge rock, the quantity of chert in the beds increasing southwards. The Director considered that the presence of the chert series so far north at this spot pointed to quieter conditions having obtained here, whilst the unusual false-bedding and greater proportion of sand, in connection with other known facts, showed more littoral conditions than in the beds on the same horizon further south, which are not false-bedded, and contain more chert. At Coast Hill on this horizon, water, quiet enough to support sponge life, appeared to have approached nearer to the shore. 
After a halt of a few minutes for lunch, the party drove to the hollow lane south of Wotton village, where the vehicles were dismissed, the remainder of the journey being made on foot. The section in this hollow lane shows the same beds as at Coast Hill, but the succession is not complicated by a fault as at the latter locality. Walking southwards, the sandy cherts are first seen very much as above described at Coast Hill ; the junctionbed (ironstone and sandy chert) ushers in the overlying Bargates, which consist of two divisions, below (b) Calcareous grit beds, sometimes hardened into stone, sometimes loose sands, followed by (a) Pepper-and-salt sands. All these beds are described in detall on page 104 of the paper referred to, and all are well shown in this section. The normal dip of all these beds is to the south, but Dr. Hinde called attention to the dip to north, seen in the chert series in certain places in this lane. The Director stated that that was a local dip only, and that he had called attention to it, and explained it, in his report on the Excursion to Abinger, which gave a full account of the physical geology of the district. The party then entered the woodlands that cover the upper dip-slope of Leith Hill, and in a new section on the west side of Abinger Bottoin, on the footpath leading down S.S.E. at 12 chains south of the extreme butt of the Rifle Range, examined the junction of the upper division (northern facies) and lower division (southern facies) of the Leith Hill chert series. The upper beds, the sandy chert beds, are as already described, but with more chert and less sand; only one bed of the lower division is shown in this pit, the bed of massive greens ind with occasional cavities with sponge spicules. In many sections this bed appears to mark an abrupt change of conditions; it belongs, however, to a series of massive rocks, never false bedded, containing thick beds of brown chert, still, however, with thin, sandy cherts and sandstones in places. In this immediate neighbourhood this massive greensand-bed is so constant below the sandy chert series, that a casual observer would be excused in mistaking it for a definite horizon ; to the east, however, and south, particularly at Coldharbour, similar rock is found in more than one bed, and certainly not at the top of the series. The next pit visited was that on the opposite (east) side of Abinger Bottom, which the Excursion in 1893 failed to attain. This section is described in the report of that Excursion; the beds are the same as those just described on the west side of the Bottom. The Director here stated that the working of this comparatively new pit had ceased since his paper was written. During the last five years a change had taken place upon Leith Hill in the method of obtaining road metal, for which there was a considerable demand. The old deep quarries were abandoned because it was found cheaper to scratch up and sift the partially disintegrated chert immediately below the turf, the labour erstwhile performed by the 
s.

Usual Position of the Escarpment.

N.

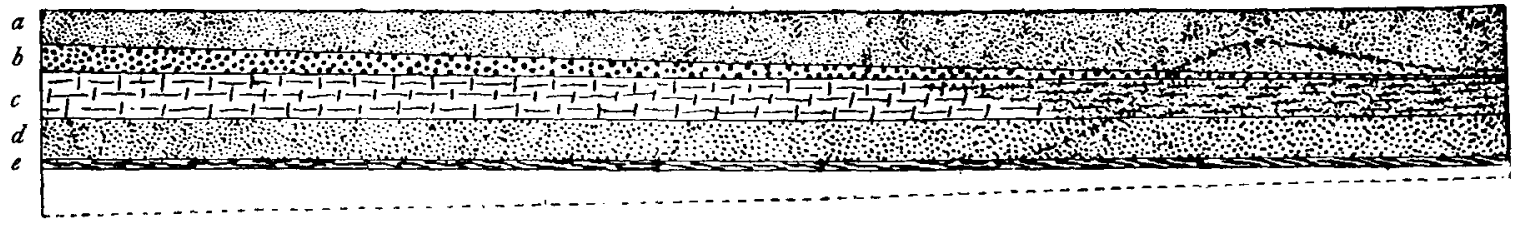

Diagram to illustrate the Deposition of the Lower GreENSAND in East Surrey.T. Lighton.

Reprinted by permission from the Quarterly Fournal of the Geological Society, Vol. $5^{I}$.

a Folkestone Sands.

$b$ Bargate Beds.

$c$ Chert Beds in the south (Local Group No. 2) passing northward into clayey Sands (Local Group No. 3). $d$ Iron Sands (Local Group No. 4).

$e$ Atherfield Clay.

ב 
"professional geologist" being now contributed by the "geological agent " known as "surface action." On the walk to the tower at the top of the hill a large number of these surface scratchings were examined. This economical change is greatly to be deplored from the geologist's point of view, because the old deep sections are rapidly weathering down.

After tea at the tower the party walked to Cockshot Hollow, and examined, below the chert series, the iron sands (Local Group 4), which everywhere in Surrey overlie the Atherfield Clay. Upon re-ascending to the path to Coldharbour the Director called attention to the outcrop of the lower Leith Hill beds, with thick beds of chert, etc., in the dry torrent bed up which the footpath courses. After passing through numerous surface workings, all of which save one, the Director stated, had been started since he commenced to work in the district, the party arrived at the now disused quarry above Coldharbour, which, the Director further stated, had been abandoned since his paper was written. The once splendid section has frequently been visited by the Association in the past; it is mentioned by Drew (Topley, Weald Memoir), and the general description of the lower Leith Hill beds, on page ro4 of the Director's paper referred to, is taken from this quarry. The section is now much obscured by scree; the regular beds of hard rock still stand out, however, on the northern face, and in the centre of the quarry a slipped mass, almost entirely of solid chert, still stands out, clearly bearing evidence to what has been. Fragments, consisting of masses of sponge spicules (highly weathered chert), and specimens of the other rocks, can be obtained from the fallen débris. This is a typical section of the beds which, the Director maintains, bear evidence, (I) in themselves from their appearance, (2) from the thick sponge beds, (3) from absence of false stratification, (4) from the absence of pebble beds, and (5) from the much smaller proportion of sand interbedded with the cherts as sandy-cherts, of having been laid down in deeper water, or further from the shore, than the overlying sandy cherts which thicken to 60 feet at Coast Hill, or than the false-bedded clayey sands into which they pass north-eastwards and north-westwards. It should be noticed that the iron-sands (Local Group 4) may be seen immediately below the Coldharbour Quarry.

The examination of this section closed the geological work of the day, the party returning to town from Holmwood Station.

\section{REFERENCES.}

Geological Survey Map, Sheet 8 (Drift Edition).

Geological Survey Index Map, Sheet I2, colour-printed. Price 2/6. (This Sheet will be found very useful for day and half-day excursions.)

New Ordnance Survey Map, Sheet 286.

Six-inch Survey Map, Surrey, Sheet 33. 
1866. MEYER, C. J. A.- "Notes on the Correlation of the Cretaceous Rocks of the South-east and West of England." Geol. Mag., vol, iii.

1875. TOPLEY, W- "Geology of the Weald." Mem. Geol. Survey.

I893. Boulger, G. S., and LeightoN, T.-." On the Lower Greensand . . . between Wotton and Dorking." 'Proc. Geol. Assoc, vol, xiii.

1893. Leighton, T.-"Excursion to Abinger." Proc. Geol. Assoc, vol. xiii. 1895. LETGhton, T.-" The Lower Greensand above the Atherfield Clay of East Surrey." Quart. Fourn. Geol. Soc., vol. li.

1895. GRegory, I. W-"Excursion to Chilworth." Proc. Geol. Assoc. vol. xiv.

\section{EXCURSION TO CHINGFORD MUSEUM AND EPPING FOREST.}

Saturday, May 9Th, 1896.

Director: T. V. Holmes, F.G.S.

Excursion Secretary: W. P. D. Stebbing, F.G.S.

(Report by The DiReCtoR.)

ON arriving at Chingford Railway Station, the party turned eastward to the Chingtord Museum at Queen Elizabeth's Hunting Lodge, less than half-a-mile away. The Museum building is an ancient edifice of the Tudor period. On ascending the broad stairs the walls are seen to be largely covered by geological and other maps, and by prints and documents illustrating the past or present of the Forest district. In the large upper chamber, once the banquet-room, the chief part of the collection is placed; and here the party was met by Mr. W. Cole, curator of the Museum and secretary of the Essex Field Club.

The Director then remarked that as this was the first visit of the Geologists' Association to Epping Forest, he would offer a few general remarks on that district. The perambulation of $\mathrm{I} 64 \mathrm{I}$ showed that Epping Forest of that date consisted of 60,000 acres. But this gives the whole aren under Forest laws, not the amount of waste, uncultivated land which formed but a small proportion of the total space included in the Forest. Passing over many details, for which the reader must be referred to Mr. Buxton's excellent Guide, it may be noted that in $185^{\circ}$, owing to the policy then pursued by the Commissioners of Woods and Forests of stimulating enclosures, the Forest consisted of but 6,000 acres. Between 1850 and 1870 half this area was enclosed and partly built upon. But during the last-mentioned period a new spirit had arisen with regard to the proper treatment of open spaces, as shown by the formation of the Commons Preservation Society, which included John Stuart Mill, Professor Fawcett, Miss [JULY, 1896.] 